\title{
Forage maize nutritional quality according to organic and inorganic fertilization
}

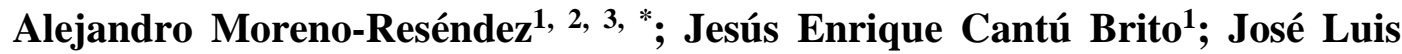 \\ Reyes-Carrillo $^{1,2,3}$; Viridiana Contreras-Villarreal ${ }^{1}$
}

${ }^{1}$ Universidad Autónoma Agraria Antonio Narro, Unidad Laguna. Periférico Raúl López Sánchez km 1.5, Carretera a Santa Fe s/n., C.P. 27059, Torreón, Coahuila de Zaragoza, Mexico.

2 Integrantes del Cuerpo Académico Sistemas Sustentables para la Producción Agropecuaria (CASISUPA), Clave: UAAAN-CA-14, Torreón, Coahuila de Zaragoza, Mexico

${ }^{3}$ Integrantes de la Red Académica de Innovación en Alimentos y Agricultura Sustentable (RAIAAS) auspiciada por el Consejo Estatal de Ciencia y Tecnología del Estado de Coahuila de Zaragoza y la Comunidad de Instituciones de Educación Superior de la Laguna (COECYT-CIESLAG), Torreón, Coahuila de Zaragoza, Mexico.

Received February 10, 2017. Accepted June 16, 2017.

\begin{abstract}
The research was conducted on a commercial land plot from the ejido Granada, municipality of Matamoros, Coahuila, situated inside the Comarca Lagunera, from April to August 2015, in order to establish the effect of two fertilization sources - organic and inorganic, upon the nutritional quality of forage maize during the spring-summer cycle with a randomized block experimental design. $\mathrm{T}_{1}=$ Acadian soil + Acadian foliage (marine algae extracts) and $\mathrm{T}_{2}=$ Regional control, with 16 replications. The evaluated variables were the

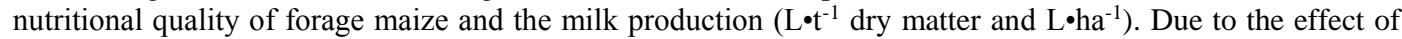
the evaluated treatments, statistical differences were registered, both for, nutritional values of forage maize, such as: neutral and acid detergent fiber, non-fiber carbohydrates, total digestible nutrients, total net energy for lactation and for milk production, in favor of organic fertilization. Therefore, it can be concluded that fertilizers of marine origin applied to forage maize increased both nutritional quality of forage maize and milk yield per ton of dry matter and per hectare of this forage.
\end{abstract}

Keywords: Crude protein; forage; milk yield; organic fertilizers.

\section{Introduction}

The Comarca Lagunera region has been considered through the time as one of the most important dairy basins from Mexico (Pedroza-Sandoval et al., 2014), this production is mainly based upon the intensive growth of high quality forage as alfalfa (Medicago sativa L.), maize (Zea mays L.) and forage sorghum (Sorghum spp.), during spring and summer, and oats (Avena spp.), wheat (Triticum aestivum L.) and triticale (Triticosecale spp.) during winter (Zamora-Villa et al., 2016) from which the raw materials used to elaborate the cattle's feed are obtained. In order to satisfy the growing demand of forage and being able to feed the dairy cattle of this region, it has been necessary to establish large acreages for these forages, especially for maize and sorghum. In this matter, statistics indicate that approximately 27,486 ha of forage maize were sown in the Comarca Lagunera, from which 12,923 ha corresponded to the Laguna from Coahuila and 14,563 ha to the Laguna of Durango (SIAP-SAGARPA, 2014).

The farming of maize for forage production constitutes a fast way of obtaining high dry matter production rates and an ideal quality for cattle feeding when it is administered either as fresh forage or as silage (Boschini and Amador, 2001; Iqbal et al., 2015). Furthermore, this forage, while fresh, has a 7.2 to $8.5 \%$ of

\footnotetext{
* Corresponding author

E-mail: alejamorsa@yahoo.com.mx (A. Moreno-Reséndez).
} 
protein, from 32.5 to $33.5 \%$ of crude fiber, from 1 to $2.5 \%$ of fat, besides containing high quantities of carbohydrates, it has the potential of providing an energy rich material for cattle feeding and of being used at all levels of production without damages derived from oxalic acid or hydrocyanic acid (prussic), as is the case with sorghum (Dahmardeh, 2011).

Plant nutrition is one of the fundamental factors affecting crop production and it plays an essential role in guaranteeing the right performance of forages. In fact, plant nutrition management is one of the main strategies for increasing crop yield and forage maize is not the exception. In the nutrition process, nitrogen and phosphorus have great relevance because they are the nutritious elements with the highest transcendence in yield as well as in the quality attributes of green forage (Iqbal et al., 2015).

On the nutritional aspect, Fortis-Hernández et al. (2009) highlighted that high quality forage production, without the use of synthetic fertilizers, is a necessity in regions where there is a marked limitation of natural resources. Also, it is highly recognized that, because of the increment of anthropogenic activities, all ecosystems have been impacted by the release of polluting agents such as heavy metals, pathogens, pesticides and synthetic fertilizers, modification of natural conditions, situation that gets reflected upon human health (García-Gutiérrez and Rodríguez-Meza, 2012). Due to these constraints, together with the constant increment of inorganic fertilizer prices, on the last few years, rethinking the situation and the search for alternatives to diminish the use of synthesis soluble fertilizers has been motivated (Contreras et al., 2014).

A recent alternative to the use of synthetic fertilizers has been the application of diverse organic fertilizers that contain a part of $\mathrm{N}$ in organic forms, more or less stable, which gets mineralized on a gradual way and become available for the growing plant, for which reason, synthetic fertilizers could be replaced by these materials (Ramos-Agüero and TerryAlfonso, 2014). One of the alternatives that has the interest of both researchers and agronomic producers is the extract from sea algae, being one of the reasons that these grow fast, produce a great biomass volume and are a source of many substances with biologic activity (Bettiol, 2006) and in this way, Zermeño-González et al. (2015) highlighted that the use of sea algae extracts as biofertilizers to the soil and foliage increases the performance and quality of different crops, this is related to the photosynthesis rate of the plants. Also, it has been put into view that these extracts contains nutritious macro and micro elements, organic compounds such as auxin and gibberellins that favor plant growth besides increasing crop yield and plant vigour against adverse environmental effects (Arun et al., 2014; Aymen et al., 2014), for these reasons, these biofertilizers, applied to the soil or foliage, could be used with the purpose of replacing, totally or partially, conventional fertilizers (Hernández-Herrera et al., 2014). Because of the above mentioned, the effect of liquid organic sea originated fertilizers, Acadian Soil and Acadian Foliage (Stimplex®), upon nutritional value of forage maize during springsummer 2015 cycle was evaluated.

\section{Materials and methods}

The experimental place, with an extension of 22 ha, known as the "Tablas de Solima", is located inside de Comarca Lagunera $\left(101^{\circ} 41^{\prime}\right.$ and $104^{\circ} 61^{\prime} \mathrm{W}$, and $24^{\circ} 59^{\prime}$ and $26^{\circ} 53^{\prime} \mathrm{N}$, with $1100 \mathrm{~m}$ average altitude, its climate is dry, desert-like, the annual mean precipitation is $258 \mathrm{~mm}$, and annual mean temperature is $2{ }^{\circ} \mathrm{C}$ (García, 1973), at approximately $5 \mathrm{~km}$ from the "La Partida-Granada" road, municipality of Matamoros, Coahuila.

The research was carried out in April August 2015 period. The surface, whose previous crop, in summer, was maize, was plowed and tracked as is traditionally done. Sowing of yellow hybrid 2A120 
corn seeds (Dow® AgroSciences of México, S.A de C.V.) with $99 \%$ purity, was done dry planting on April 20, 2015, placing from six to seven seeds per lineal meter, in order to achieve a population density $c a$. 60,000 plants $\bullet \mathrm{ha}^{-1}$. The first irrigation took place four days afterwards, in total, four auxiliary irrigations were applied, distributed with an interval of 28 to 30 days with a total irrigation lamina of $80 \mathrm{~cm}$, for which a system with an alfalfa valve was used (Delgado-Ramírez et al., 2013).

The fertilizing treatments were:

T1: Acadian soil [seed inoculation $(200 \mathrm{~mL} \cdot 20$ $\mathrm{kg}^{-1}$ seed) and applied to soil on the $2^{\circ}$ and $3^{\circ}$ auxiliary irrigation $\left(0.5 \mathrm{~L}^{\circ} \mathrm{ha}^{-1}\right.$ $\left.\left.^{\text {irrigation }}{ }^{-1}\right)\right]+$ Acadian foliage (Stimplex) [two applications

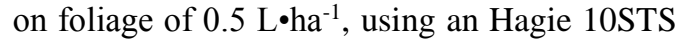
sprinkler system Hagie ${ }^{\circledR}$ Inc. USA, when the plants presented four to six true leaves]

T2: Regional control. At sowing, the dose 5080-00 was applied using $\left(\mathrm{NH}_{4}\right)_{2} \mathrm{SO}_{4}$ and monoammonium phosphate (MAP) with a dose of 140-00-00 (N-P-K) at first auxiliary irrigation using urea fertilizer. The Acadian Soil and Acadian Foliage products (Stimplex) were obtained from the Acadian Sea plants Mexicana, S.A. de C.V. Inc®.

Acadian Soil is a formulation specially designed to be applied to the soil $(\mathrm{pH}$ of 7.8-8.2 with an OMRI and BSC certification) and the Acadian Foliage (Stimplex) is a formulation specially designed to be applied to the foliage ( $\mathrm{pH}$ of 3.6-4.2 with an OMRI and BSC certification). Its chemical composition includes: $0.34,6.84,14.16,3.95,0.168$, $0.23 \%$ of $\mathrm{N}, \mathrm{K}, \mathrm{MO}, \mathrm{S}, \mathrm{Ca}, \mathrm{Mg}$, as well as 64.5, 40.2, 3.6 and 7.5 ppm de B, Fe, Mn and $\mathrm{Zn}$, respectively. Meanwhile, Stimplex composition contains: $0.3,1.0,4.0,8.0$, $0.5,0.05,15.0,5.0 \%$ of $\mathrm{N}, \mathrm{P}, \mathrm{K}, \mathrm{MO}, \mathrm{S}$, $\mathrm{Mg}$, Bo and $\mathrm{Zn}$, respectively, as well as 280 ppm of Ca (Terralia, 2016).

The programed cutting date, 90 days after sowing (das), was delayed to 112 das because an extraordinary rainfall. At the harvest green samples were obtained from each treatment and repetition, these were laid in paper bags, properly labeled, for their transfer to the laboratory AGLOLAB of México and, after registering their weight, they were laid on a forced air oven at $72{ }^{\circ} \mathrm{C}$ for a period of $24 \mathrm{~h}$. On dry foliage, in addition to determining the quality of dry matter (DM), using the technique of near infrared spectroscopy (NIRS), the following variables were evaluated: crude protein (CP) content, acid detergent fiber (ADF) content, neutral detergent fiber (NDF) content, non-fibrous carbohydrates (NFC), total digestible nutrients (TDN) and net energy for lactation (NEL), in mega calories per kilogram of dry matter. Finally, the potential milk productions per ton of dry matter and per hectare were determined using the Milk 2006® software (Shaver et al., 2006).

For the experiment, a completely randomized block design with two treatments and 16 replications was used. The statistical analyzes for the studied variables were done using an analysis of variance and the mean separation by the least significant difference test $\left(\mathrm{LSD}_{0.05}\right)$ (Olivares-Sáenz, 1993).

\section{Results and discussion}

The analysis of variance applied registered significant differences $(p \leq 0.05)$ for the $\mathrm{CP}, \mathrm{ADF}, \mathrm{NDF}, \mathrm{NFC}, \mathrm{TDN}$ and NEL variables (Table 1). As can be seen on that table, the application of organic fertilizers favored increments in four of the six quality variables from the research: $\mathrm{CP}$, ADF, NDF and TDN. In accordance with Schwab et al. (2003) concentrations of CP, NDF and NFC and digestibility of these components impact the energetic value of forages.

\section{Crude protein content}

In regard to $\mathrm{CP}$, forage maize treated with organic fertilizers surpassed forage maize treated with inorganic fertilizers in $10.41 \%$. Values obtained for CP (Table 1) were slightly higher at the mean interval, from 7.9 to $9.1 \%$, than the CP reported for different forage maize hybrids intermediate and precocious - evaluated in 
the Comarca Lagunera (INIFAP, 2006). On the other hand, values obtained both with organic and inorganic fertilization at 112 das in the present study surpassed CP values, $7.8,7.4$ and $6.5 \%$ reported by Amodu et al. (2014) for two varieties of forage maize in three different harvest dates, at 91, 105 and 119 das, respectively. Nonetheless, results obtained differ from that established by Hassan-Amin (2010) who when evaluation organic and inorganic fertilization upon growth, quality and yield of forage maize from Giza - 2 and Mugtama - 45 cultivars during two consecutive productive cycles in Sudan determined that there were no significant differences registered both for cultivars and fertilization -organic vs inorganiceffects in both production cycles registering $\mathrm{CP}$ values that oscillated between 6.3 and $6.7 \%$. On the present research, organic fertilization applied to 2A120 hybrid maize significantly surpassed inorganic fertilization with $\mathrm{CP}$ values of $10.41 \%$.

Moreover, CP contents found in the present research were contrary to those established by Faisal et al. (2013) who determined that inorganic fertilization significantly surpassed organic fertilization in accordance to those characteristics. Crude protein fluctuated between values of 10.74 and $10.80 \%$ vs 9.86 and $10.05 \%$, for inorganic and organic fertilization, respectively. Similarly, Fortis- Hernández et al. (2009) determined that PC with inorganic fertilization (12.68\%) surpassed registered values for the application of bio compost (10.41\%) and vermicompost (10.23\%). The highest PC, 9.6\%, registered in forage maize plants, as a result of applying organic fertilizers, could have been due in great part to these materials, besides being a source of nutrients of slow release to soil (Mulet-delPozo et al., 2008; Domínguez et al., 2010), which become available for plants as they need them (Domínguez et al., 2010) and also have high contents of $\mathrm{N}$ mineral for plant species (Ramos-Agüero and TerryAlfonso, 2014), element that is an essential content of amino acids, basic units of proteins (Rasheed et al., (2004). Furthermore, it can be highlighted that a food or a diet has to have a $7 \%$ of $\mathrm{CP}$ content to guaranty an enough supply of nitrogen for an effective ruminal microbial fermentation (Oramas-Wenholz and VivasQuila, 2007), value that was easily covered as a result of applying organic fertilization.

\section{Acid detergent fiber}

The ADF is used to estimate energetic value of maize silage (INIFAP, 2006) and, because it is constituted from cellulose, lignin and proteins, it is the component that is most related to forage digestibility (Castillo-Jiménez et al., 2009) the more content of this fiber, the less digestibility of the materials (INIFAP, 2006). For fodder crops to be considered of quality, it is necessary that they have ADF values lower than 28\% (Gallegos-Ponce et al., 2012 ), value that was surpassed by $7.5 \%$ of ADF content of forage maize treated with organic fertilization (Table 1).

\section{Table 1}

Mean values and statistical significance of dry matter quality values of forage maize developped with different sources of fertilization, organic and inorganic, in the Comarca Lagunera

\begin{tabular}{ccccccc}
\hline \multirow{2}{*}{ Treatment } & CP & ADF & NDF & NFC & TDN & \\
\cline { 2 - 5 } & \multicolumn{5}{c}{$(\%)$} & $\begin{array}{c}\text { NEL } \\
\left(\mathrm{Mcal} \bullet \mathrm{kg}^{-1}\right)\end{array}$ \\
\hline T1 & $9.6 \mathrm{a}$ & $35.9 \mathrm{a}$ & $53.5 \mathrm{a}$ & $21.2 \mathrm{~b}$ & $47.0 \mathrm{a}$ & $0.98 \mathrm{~b}$ \\
$\mathrm{~T} 2$ & $8.6 \mathrm{~b}$ & $27.2 \mathrm{~b}$ & $42.6 \mathrm{~b}$ & $31.4 \mathrm{a}$ & $46.0 \mathrm{~b}$ & $1.05 \mathrm{a}$ \\
\hline
\end{tabular}

$\mathrm{CP}=$ crude protein, $\mathrm{ADF}=$ acid detergent fiber $\mathrm{NDF}=$ neutral detergent fiber, $\mathrm{NFC}=$ non fibrous carbohydrates, TDN = total digestive nutrients; $\mathrm{NEL}=$ net energy for lactation. Means with different letters in columns statistically differ (LSD 0.05$)$. 
The present research showed that organic fertilization favored ADF content which surpassed $24.33 \%$ to that found in plants treated with inorganic fertilization. The interval of values obtained with the experiment (Table 1) was similar to the range reported by the INIFAP (2006) for this kind of fiber in forage maize intermediate and precocious on the Comarca Lagunera, whose values oscillated between 27.3 and $34.7 \%$. While, in accordance to FDA values reported by Amodu et al. (2014) in two maize varieties, applying synthetic fertilizers with 24.7 and $30.8 \%$, resulted slightly higher.

On the other hand, the use of organic fertilizers Vermicompost and Biocompost to the yellow maize hybrid HT90-19HR occasioned that ADF content reached values that oscillated between 26.5 and $28.7 \%$, while Salazar-Sosa et al. (2007),

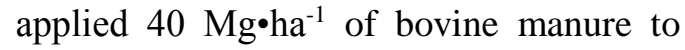
the Saint Lorenzo maize variety and reported values of $28 \%$. These values were surpassed in at least $20.05 \%$ of FDA content to those values found on the present research, which were of $35.9 \%$, when organic fertilization was applied. Content that could reduce dry matter intake of the forage maize evaluated because of the higher content of cell wall components (Castillo-Jiménez et al., 2009).

\section{Neutral detergent fiber}

The content of NDF in forages is negatively correlated with intake and digestibility (Oramas-Wenholz and VivasQuila, 2007) so, to obtain forages with high energetic value it is necessary to use maize hybrids that contain less than $50.0 \%$ of this type of fiber (INFAP, 2006; Gallegos-Ponce et al., 2012). The NDF content registered with organic fertilization (Table 1) surpassed by $7 \%$ to the reference value.

The FDN values of forage maize from the present experiment (Table 1) resulted inferior that the mean interval of 33.7 and $59.8 \%$ of NDF values reported for 11 hybrids of temperate origin and seven or tropical origin (Núñez-Hernández et al.,
2004) and likewise resulted inferior to the mean interval of 48.3 and $59.3 \%$ reported for this type of fiber found in forage maize - intermediate and precocious - all of them developed with inorganic fertilization in the Comarca Lagunera region (INIFAP, 2006). Also, they were surpassed by mean NDF contents of $66.31 \%$ reported for five maize genotypes developed under limited irrigation and treated with inorganic fertilization also from the Comarca Lagunera region (Gallegos-Ponce et al., 2012).

The $53.5 \%$ content of NDF, obtained in forage maize treated with organic fertilization, was surpassed in at least $8 \%$ by the mean NDF value, $58.25 \%$, reported by Amodu et al. (2014) for forage maize treated with inorganic fertilization.

The use of Vermicompost and Biocompost in forage maize favored the NDF content whose values ranged between 49.5 and $51.7 \%$ (Fortis-Hernández et al., 2009), which were slightly different to the NDF value obtained with organic fertilization applied to hybrid forage maize from the present experiment (Table 1). On the same sense, the administration of 0 to 160 $\mathrm{Mg} \cdot \mathrm{ha}^{-1}$ of bovine manure to Saint Lorenzo forage maize, by these authors, gave as a result a mean value of $47.88 \%$, value that also resulted inferior to the $53.5 \%$ NDF value obtained in the present study.

\section{Non fibrous carbohydrates}

Carbohydrates are diverse (free sugars, fructans, hemicellulose, cellulose, and so on) and can be classified in fibrous (structural) and non-fibrous fractions (nonstructural or for reserve). The ratio as well as the digestibility of fiber affects forage energy (INIFAP, 2006; Martínez-Marín, 2008).

Contrary to the behavior observed for $\mathrm{CP}$, for ADF and NDF, NFC was significantly favored by inorganic fertilization in comparison to organic fertilization (table 1). Contrary to that stablished by UrrutiaMorales et al. (2014), who reported that the highest contents of NDF and NFC reduce digestibility of materials, on this 
research the reduction of digestibility of forage maize could be due only to the NDF content and not the NFC content that was registered on plants treated with organic fertilizers.

The NFC content registered on this experimental study with organic fertilization was $32.5 \%$ lower than the value obtained with inorganic fertilization. Similarly, it resulted 35\% lower than the mean values for NFC reported by RetaSánchez et al. (2010) for developed maize on the spring and summer cycles on the Comarca Lagunera region and those reported by Corral-Luna et al. (2013) for five maize hybrids developed on the central region of the Chihuahua state in Mexico, it was also slightly inferior to the 21.7 and $23.8 \%$ NFD values reported by Reta-Sánchez et al. (2013) for four leguminous species also from the Comarca Lagunera, during the 2005 and 2006 productive cycles, respectively.

\section{Total digestible nutrients}

The TDN, as an expression unit of the energy content of feed, constitutes and approximate measure unit of the digestibility of these (Posada et al., 2012). Again, for this variable in forage maize, organic fertilization significantly surpassed inorganic fertilization (Table 1). Nonetheless, taking into account what OlagueRamírez et al. (2006) stated in respect to this characteristic which is that high quality forage should have values equal or higher that $65 \%$ of TDN, the obtained values both for organic and inorganic fertilization, 47.0 and $46.0 \%$ respectively, allows us to signal that yellow 2A120 hybrid maize evaluated on the present research can be considered as of lower forage quality.

Meanwhile, Kim et al. (2001), when evaluating five maize hybrids in five different harvest dates, determined that the mean value at 111 das, which is similar to the harvest dates of this research, was an optimum TDN value of $64.6 \%$, which surpassed in $27.2 \%$ the value obtained with organic fertilization

\section{Net energy for lactation}

The energetic requirements for maintenance and milk production are expressed as net energy for lactation (NEL). As with NFC content, in respect to NEL, inorganic fertilization was significantly surpassed by the organic fertilization (table 1). Values of 0.98 and $1.05 \mathrm{Mcal} \cdot \mathrm{kg}^{-1}$ of DM, were surpassed in at least $30 \%$ of NEL by the mean value reported by Núñez-Hernández et al. (2010), who studied 21 forage maize varieties in the Comarca Lagunera, they determined a mean value of $1.52 \mathrm{Mcal} \cdot \mathrm{kg}^{-1}$ of DM with inorganic fertilization.

The low values of NEL registered in both treatments could be due in a great part, as stated by Peña-Ramos et al. (2002), Núñez-Hernández et al. (2004) and de la Cruz-Lázaro et al. (2007), to the fact that selection programs used to develop forage hybrids give a higher relevance to forage yield per surface unit than nutritional value of the materials. Besides, the same authors signal that maize silage presents NEL values that oscillate between 1.3 and 1.5 Mcal $\bullet \mathrm{kg}^{-1}$ of DM, which also highly surpassed NEL values determined on the present research (Table 1).

\section{Forage quality}

Finally, organic fertilization of yellow hybrid 2A120 maize generated an average quality forage because values registered on the research were slightly inferior or similar to values reported by OlagueRamírez et al. (2006) and Zamora-Villa et al. (2016), the first authors established that maize with a high forage quality should have values of $10,28.56,54.41$ and $59.71 \%$ for $\mathrm{CP}, \mathrm{ADF}, \mathrm{NDF}$ and TDN, respectively, as well as $1.22 \mathrm{Mcal} \cdot \mathrm{kg}^{-1}$ of DM. Meanwhile, the second authors determined that forages of low quality have values higher than 35 and $60 \%$ of ADF and NDF, respectively with a NEL lower than $1.4 \mathrm{Mcal} \bullet \mathrm{kg}^{-1}$ of DM.

\section{Milk production in liters}

The use of the Milk 2006 software from the Wisconsin University, which was fed with the data from the evaluated variables, allowed us to predict quantities equivalent 
to liters of milk per ton of dry matter and per hectare. According to kilograms of milk per ton of dry matter, the obtained values for organic and inorganic fertilization were 764 and $765 \mathrm{~kg}^{\bullet} \boldsymbol{\bullet}^{-1}$ of DM, respectively and they were slightly superior to the mean value of $751 \mathrm{~kg} \cdot \mathrm{t}^{-1}$ of DM, reported by Peña-Ramos et al. (2006) who evaluated two precocious maize hybrids using different sowing dates, $\mathrm{N}$ doses and population density. Results of this research surpassed in at least $31 \%$ the

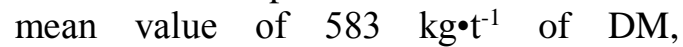
determined by González-Castañeda et al. (2006) for two maize hybrids - one precocious (Halcón by Asgrow®) and another of intermediate cycle $(3028 \mathrm{~W}$ by Pionner ${ }^{\circledR}$ ) - applying inorganic fertilizers.

Meanwhile, milk production in tons per hectare, which is of higher interest for producers because it allows us to define if we want to harvest liters of water or liters of milk, a decision that has as support the selection of the hybrid that is being considered for sowing and the harvest date. As a result of applying organic or inorganic fertilization, a production of 15.4 and $13.7 \mathrm{t}^{\circ} \mathrm{ha}^{-1}$, respectively was estimated. Milk production with organic fertilization surpassed by $6.5 \%$ the mean value of $14.4 \mathrm{t}$ $\cdot \mathrm{ha}^{-1}$, reported by Peña-Ramos et al. (2006), who used inorganic sources of fertilization. Also, it surpassed in $30 \%$ the mean value of $10.71 \mathrm{t} \cdot$ ha $^{-1}$, determined by González-Castañeda et al. (2006) in two maize hybrids with the management described on the previous paragraph. In addition, it resulted to be similar to the maximum value of milk production determined by Peña-Ramos et al. (2002) who reported values that oscillated between 6.7 and $15.5 \mathrm{t} \cdot \mathrm{ha}^{-1}$, while evaluating 19 populations and six commercial hybrids in two locations Pabellón in Aguascalientes and Torreón in Coahuila - applying inorganic fertilization.

\section{Conclusions}

We conclude that it is feasible to obtain a higher nutritional value of spring forage maize with the administration of Acadian soil and Stimplex, because there was a favorable effect in relation to the response to these organic fertilizers. Forage harvested in general was considered about the average quality although results obtained showed inferior values to those used as reference in forage material. The afore mentioned could be due to the maturity state of the crop since harvest was delayed for 22 days by rain.

\section{Acknowledgments}

To Acadian Sea plants Inc. and Dr. Pedro A. Cerda García, Market Development Scientist Latin America, for supplying the products used on this research and for the support given throughout the experiment.

\section{References}

Amodu J.T.; Akpensuen, T.T.; Dung, D.D.; Tanko, R.J.; Musa, A.; Abubakar, S.A.; Hassan, M.R.; Jegede, J.O.; Sani, I. 2014. Evaluation of maize accessions for nutrients composition, forage and silage yields. Journal Agricultural Science 6(4): 178-187.

Arun D.; Gayathri, P.K.; Chandran, M.; Yuvaraj, D. 2014. Studies on effect of seaweed extracts on crop plants and microbes. International Journal of ChemTech Research 6(9): 4235-4240.

Aymen, E.M.; Salma, L.; Halima, C.; Cherif, H.; Mimoun, E. 2014. Effect of seaweed extract of sargassum vulgare on germination behavior of two tomatoes cultivars (Solanum lycopersicum L.) under salt stress. Octa Journal of Environmental Research 2: 203-210.

Bettiol, W. 2006. Productos alternativos para el manejo de enfermedades en cultivos comerciales. Fitosanidad 10(2): 85-98.

Boschini, C.; Amador, A.L. 2001. Ruminal degradability of corn in different stages of growth. Agronomía Mesoamericana 12(1): 89-94.

Castillo-Jiménez, M.; Rojas-Bourrillón, A.; WingChingJones, R. 2009. Nutritional value of silage made with a mixture of corn and mung bean (Vigna radiata). Agronomía Costarricense 33(1): 133-146.

Contreras, J.I.; Cánovas, G.; Baeza, R. 2014. Aplicación en fondo de fertilizantes organominerales como alternativa a la fertirrigación convencional en cultivos hortícolas: II. Efecto sobre la dinámica de producción de frutos y nutrientes en suelo. In: $\mathrm{V}$ Jornadas Fertilización SECH. Actas de Horticultura 66: 59-64.

Corral-Luna, A.; Domínguez-Díaz, D.; Murphy, M.R.; Rodríguez-Almeida, F.A.; Villalobos, G.; OrtegaGutiérrez, J.A. 2013. Relationships between chemical composition, in vitro dry matter, neutral detergent fiber digestibility and in vitro gas production of corn and sorghum silages. Journal of Animal and Veterinary Advances 12(20): 1524-1529.

Dahmardeh, M. 2011. Effect of plant density and nitrogen rates on PAR absorption and maize yield. American Journal of Plant Physiology 6(1): 44-49. 
Delgado-Ramírez, G.; Estrada-Ávalos, J.; Trucíos-Caciano, R.; Rivera-González, M.; Catalán-Valencia, E.A. 2013. Methodology to evaluate global irrigation efficiency in systems with alfalfera valves: lagunera region case. Revista Chapingo Serie Zonas Áridas 12(1): 3-6.

de la Cruz-Lázaro, E.; Rodríguez-Herrera, S.A.; PalomoGil, A.; López Benítez, A.; Robledo-Torres, V.; Gómez-Vázquez, A.; Osorio-Osorio, R. 2007. Combining ability of protein high quality maíz inbred lines for forage characteristics. Ecosistemas y Recursos Agropecuarios 23(1): 57-67.

Domínguez, J.; Gómez-Brandón, M.; Lazcano, C. 2010. Bio-pesticide properties of vermicompost. Acta Zoológica Mexicana 26(spe2): 373-383.

Faisal, S.; Shah, S.N.M.; Majid, A.; Khan, A. 2013. Effect of organic and inorganic fertilizers on protein, yield and related traits of maize varieties. International Journal of Agriculture and Crop Sciences 6(18): 12991303.

Fortis-Hernández, M.; Leos-Rodríguez, J.A.; PreciadoRangel, P.; Orona-Castillo, I.; García-Salazar, J.A.; García-Hernández, J.L.; Orozco-Vidal, J.A. 2009. Application of organic fertilizers in the production of forage corn with drip irrigation. Terra Latinoamericana 27(4): 329-336.

Gallegos-Ponce, A.; Martínez-Ríos, A.; Fernando-Sánchez, M.; Figueroa-Viramontes, R.; Berumen-Padilla, S.; Venegas-Soto, J.; Quevedo-Guillen, J. de D.; Escobedo-López, D.; Silos-Calzada, M.C. 2012. Nutritional quality of forage maize (Zea mays L.) under limited water logging conditions. AGROFAZ 12(1): 59-66.

García, E. 1973. Modificaciones al Sistema de Clasificación Climática de Köppen. México, DF: Instituto de Geografía. UNAM.

García-Gutiérrez， C.; Rodríguez-Meza， G.D. 2012. Environmental problems and risk for the use of pesticides in Sinaloa. Ra Ximhai 8(3): 1-10.

González-Castañeda, F.; Peña-Ramos, A.; NúñezHernández, G. 2006. Harvest stages, forage yield and quality of corn hybrids with different biological cycle. Revista Fitotecnia Mexicana 29(Es2): 103-107.

Hassan-Amin, M. EL-Murtada. 2010. Effect of organic fertilizer and urea on growth, yield and quality of fodder maize (Zea mays L.). International Journal of Current Research 8: 35-41.

Hernández-Herrera, R.M.; Santacruz-Ruvalcaba, F.; RuizLópez, M.A.; Norrie, J.; Hernández-Carmona, G. 2014. Effect of liquid seaweed extracts on growth of tomato seedlings (Solanum lycopersicum L.). Journal of Applied Phycology 26(1): 619-628.

Instituto Nacional de Investigaciones Forestales, Agrícolas y Pecuarias (INIFAP). 2006. Maíz forrajero de alto rendimiento y calidad nutricional. Libro Científico No. 3. Ed. $1^{\mathrm{a}}$ ed. México. Instituto Nacional de Investigaciones Forestales Agrícolas y Pecuarias. Available in:

http://biblioteca.inifap.gob.mx:8080/jspui/bitstream/ha ndle/123456789/1950/Maiz\%20forrajero\%20de\%20alt o\%20rendimiento\%20y\%20calidad\%20nutricional.pdf ?sequence $=1$.

Iqbal, M.A.; Iqbal, A.; Ahmad, A.; Raza, A.; Nabeel, F. 2015. Overviewing forage maize yield and quality attributes enhancement with plant nutrition management. World Journal of Agricultural Sciences 11(3): 128-134.

Kim, J.D.; Kwon, C.H.; Kim, D.A. 2001. Yield and quality of silage corn as affected by hybrid maturity, planting date and harvest stage. Asian Australasian Journal of Animal Sciences 14(12): 1705-1711.

Martínez-Marín, A.L. 2008. Nutritional factors to be considered when designing diets of dry roughages and concentrates for hand-fed, leisure horses. Revista Electrónica de Veterinaria 9(3): 1-20.

Mulet-del-Pozo, Y.; Díaz-Álvarez, M.E.; Vilches-León, E. E. 2008. Determination of some physique mechanical, chemical and biological properties of the worm humus obtained under conditions of the dairy farm Guayabal, San José de las Lajas, La Habana, Cuba. Revista Ciencias Técnicas Agropecuarias 17(1): 27-30.

Núñez-Hernández G.; Contreras, G.F.; Faz-Contreras, R. 2004. Yield, chemical composition and in vitro digestibility of tropical and temperate corn hybrids in the arid region of Mexico. Avances en Investigación Agropecuaria 8(1): 1-9.

Núñez-Hernández, G.; Payán-García, J.A.; Pena-Ramos, A.; González-Castañeda, F.; Ruiz-Barrera, O.; ArzolaÁlvarez, C. 2010. Forage quality and agronomic characterization of annual forage species in NorthCentral Mexico. Revista Mexicana de Ciencias Pecuarias 1(2): 85-98.

Olague-Ramírez, J.; Montemayor-Trejo, J.A.; BravoSánchez, S.R.; Fortis-Hernández, M.; Aldaco-Nuncio R. A.; Ruiz-Cerda, E. 2006. Agronomic characteristic and forage quality corn with subsurface drip irrigation. Técnica Pecuaria México 44(3): 351-357.

Olivares-Sáenz, E. 1993. Diseño experimental Software. V. 2.4. México, DF: Facultad de Agronomía - UANL. Marín, N. L., México.

Oramas-Wenholz, C.; Vivas-Quila, N.J. 2007. Evaluation of two hybrids and one variety of corn (Zea mays) in intensive crop and association with pean (Phaseolus vulgaris), for silage. Revista de la Facultad de Ciencias Agropecuarias 5(1): 28-35.

Pedroza-Sandoval, A.; Ríos-Flores, J.L.; Torres-Moreno, M.; Cantú-Brito, J.E.; Piceno-Sagarnaga, C.; YáñezChávez, L.G. 2014.Irrigation water efficiency in the forage corn (Zea mays L.) and alfalfa (Medicago sativa) production and its social and economic impact. Terra Latinoamericana 32(3): 231-239.

Peña-Ramos, A.; Núñez-Hernández, G.; GonzálezCastañeda, F. 2002. Forage potential of some maize populations and relationships between their agronomic characteristics and nutritional quality. Técnica Pecuaria México 40(3): 215-228.

Peña-Ramos, A.; González-Castañeda, F.; NúñezHernández, G.; Maciel-Pérez, L.H. 2006. Forage yield and quality of early maize hybrids in response to planting date, nitrogen and plant density. Revista Fitotecnia Mexicana 29(3): 207-213.

Posada O.S.; Rosero N.R.; Rodríguez, N.; Costa C.A. 2012. Comparison of methods to determine the energy value of feeds for ruminants. Revista MVZ Córdoba 17(3): 3184-3192.

Ramos-Agüero, D.; Terry-Alfonso, E. 2014. Generalities of the organic manures: Bocashi's importance like nutritional alternative for soil and plants. Cultivos Tropicales 35(4): 52-59.

Rasheed, M.; Ali, H.; Mahmood, T. 2004. Impact of nitrogen and sulfur application on growth and yield of maize (Zea mays L.) crop. Journal of Research (Science) 15(2): 153-157.

Reta-Sánchez, D.G.; Figueroa-Viramontes, U.; FazContreras, R.; Núñez-Hernández, G.; GaytánMascorro, A.; Serrato-Corona, J.S.; Payán-García, J. A. 2010. Forage cropping systems for increasing water 
productivity. Revista Fitotecnia Mexicana 33(4): 8387.

Salazar-Sosa, E.; Trejo-Escareño, H.I.; Vázquez-Vázquez, C.; López-Martínez, J.D. 2007. Corn production under subsurface drip irrigation and application of cow manure. International Journal of Experimental Botany 76: $169-185$

Shaver, R.; Lauer, J.; Coors, J.; Hoffman, P. 2006. MILK2006. University of Wisconsin Corn Silage Evaluation System. Available in:

http://www.foragelab.com/Media/Milk_2006_Corn_Si lagev1_Spreadsheet.xls

Schwab, E.C.; Shaver, R D.; Lauer, J.G.; Coors, J.G. 2003. Estimating silage energy value and milk yield to rank corn hybrids. Animal Feed Science and Technology 109(1-4): 1-18.

Servicio de Información Agroalimentaria y Pesquera Secretaría de Agricultura, Ganadería, Desarrollo Rural, Pesca y Alimentación (SIAP-SAGARPA). 2014. Producción agropecuaria y pesquera. Anuario Estadístico de la Producción Agropecuaria en la Región Lagunera. Coahuila y Durango. Available in: http://www.siap.gob.mx/cierre-de-la-produccionagricola-por-cultivo

Terralia. Acadian. 2016. ACADIAN Suelo, Acadian. Available in:

http://www.terralia.com/agroquimicos_de_mexico/vie w_trademark?trademark_id=9603

Urrutia-Morales, J.; Hernández-Alatorre, A.; CervantesBecerra, J.F.; Gámez-Vázquez, H. 2014. Nutritive characteristics of pearl millet forage in four phenological stages. Revista Mexicana de Ciencias Pecuarias 5(3): 321-330.

Zamora-Villa, V.M.; Colín-Rico, M.; Torres-Tapia. M.A.; Rodríguez-García, A.; Jaramillo-Sánchez, M.A. 2016. Producción y valor nutritivo en fracciones de forraje de trigos imberbes. Rev. Mex. Cienc. Agríc. 7(2): 291 300.

Zermeño-González, A.; Mendez-López, G.; RodríguezGarcía, R.; Cadena-Zapata, M.; Cárdenas-Palomo, J.O.; Catalán-Valencia, E.A. 2015.Biofertilization of a vineyard and its relationship to photosynthesis, yield and fruit quality. Agrociencia 49(8): 875-887. 